\title{
The Process of Retail Internationalization in the Chinese Market: A Case of Japanese Fashion Company
}

\author{
Miao Miao ${ }^{1}$ \\ ${ }^{1}$ Department of Contemporary Business, International Pacific University, Okayama, Japan \\ Correspondence: Miao Miao, Business Administration, Department of Contemporary Business, International \\ Pacific University, Seto-cho, Higashi-ku, Okayama, Japan, Tel: 81-86-908-0200. E-mail: \\ m.miao@ipu-japan.ac.jp
}

Received: September 10, $2017 \quad$ Accepted: September 25, $2017 \quad$ Online Published: September 30, 2017

doi:10.5539/ijms.v9n5p95 URL: http://doi.org/10.5539/ijms.v9n5p95

\begin{abstract}
Since China's ingress into the World Trade Organization (WTO), to a greater extent, multinational business enterprises have entered the market. Fashion industries, for instance, led by European and American apparel retailers, including many Japanese companies, have begun to pay attention to the Chinese market. This is embodied in diverse formats of retailing outlets with international expansions. The intent of this paper is to present an empirical study for improving the framework of retail internationalization processes in the Chinese market, and to provide a perception of the interface between retailing and building customer relationship. Case studies approach is employed in this study to build theories. The objectives of this research are (1) to investigate the processes and barriers of entering the Chinese market by looking at a case study of a Japanese fashion retailer; (2) to clarify the characteristics of each stage of international expansion by applying dynamic capabilities based on a framework that makes a distinction between a firm's first stage, second stage and third stage; and (3) to indicate the emergence of a new retail format, called a "house brand store," and its important role in retail internationalization and customer relationship management.
\end{abstract}

Keywords: retail internationalization, dynamic capability, retail format, Japanese apparel retailer

\section{Introduction}

Retail internationalization in the fashion industry is becoming important and has become the central topic of competition (Newman \& Cullen, 2002; Lavin, 2009). The changes of strategic expansion and branding are seen by retailers to be not only the ones that expand retail channels but also the ones that establish their own brands by cooperating with manufacturers to strengthen their retail operation (Olsen et al., 2010). Today, branding is no more focused on design and production. It has shifted to how to build an efficient supply chain and specialty store with high loyalty (Faultrier et al., 2014; Kremer \& Viot, 2012).

Multinational retailers are becoming burly with their holistic marketing management that give more concentration to product development and reinforce brand identity with inventive store formats and logistics systems. Therefore, the great apparel merchants, such as GAP, H\&M, ZARA, and UNIQLO, are succeeding in intensifying to the global market by overseeing both retail and product design. Much research has been done in investigating marketing novelty within the apparel industry. Some of this research showed the results of the novelty by various companies within their Supply Chain Management (SCM). Novelties include something called, "agile supply chain", which forms a quick rejoinder chain which reduces inventory cost and increases the returns produced by that supply chain (Fernie \& Nobukazu, 2004; Christopher \& Robert, 2004; Morash \& Steven, 2001; Minam et al., 2012).

Since 2000 , more and more merchants have anticipated to grow faster and benefit by building a hefty value chain across borders. They wish to penetrate into the global markets and create a global network, despite the fact that internationalization does not have a momentous effect on retailers' returns growth rates or their profit margins (Corstjens \& Lal, 2012).

The anxiety from local markets and the benefits of globalization caused many merchants to venture abroad to quest for greater economies of scale, and they craved to attract unsullied talents and create new opportunities for existing leaders, etc (Corstjens \& Lal, 2012). However, there still exist many barricades for entering the foreign 
markets, i.e., estate cost, entrenched rivalry, and lack of appropriate sites and information about new markets. According to Corstjens \& Lal (2012), the high prospects of consumers, unfair competition with local retailers by protectionist laws are also potentially injurious to international retailers' interests.

For these problems of international development, Wigley \& Moore (2007) pointed that triumphant international retailing requires the coherent expression of the brand, striking products, competent distribution and retail operations by comparing with two fashion retailers in USA and UK. Their research highlights the sentiment that an internationalizing fashion retailer must maintain control over how the information flows between every unit of the business. That is, it shows that controlling information is one of the top precedence in retail processes.

According to Pitelis \& Teece (2010), international retailing requires flexibility, agility, entrepreneurship, learning, and investment choices. It means that retailers should build up new capabilities to adapt their business models to thrive in new markets. Pitelis \& Teece (2010) suggested that much of this internationalization process could be experimental by a vibrant capabilities approach.

This paper consists of four parts. First, the previous studies that highlight the internationalization process in retail and the dynamic capabilities approach. The context and methodology of this paper are explained, and based on an empirical study of a major Japanese fashion retailer, we observe that there are barricades in expanding to the Chinese market which are conquered by the implementation of three -stage dynamic capabilities, which are differentiated by retail operation and channel management, and product adaptation. Finally, discussions and conclusions are stated.

\section{Literature Review}

\subsection{Retail Internationalization}

Retail internationalization existing studies have analyzed the entry mode and expansion mode of companies as they expand into the foreign markets. The research in international retailing has focused on the speed and direction of the growth of companies and their aggressive processes in foreign markets (Frasquet et al., 2013).

In the process of international growth, retailers are required to decipher suitable strategies and foreign operation modes which minimize risk and maximize the potential for success (Deloitte, 2009). The decision of the growth mode is connected to the retailer's international marketing policy, such as the underlying marketing strategy and retail format, as well as their products and services (Goldman, 2001).

According to Picot-Coupey et al. (2012), there are five types of fashion retail formats with different characteristics and effects. As companies develop into foreign markets, they may attempt a variety of expansion modes, each of which might be greatly affected by various factors. For instance, the examination highlighted that the company-owned stores as a development mode has a high degree of specific asset protection and requires a willingness to commit resources, and also requires constant development. Beyond that, for the research of internationalization processes, dynamic capability has been highlighted as an imperative approach and outline. Dynamic capability has been defined as "the firm's ability to integrate, build, and reconfigure internal and external competencies to address rapidly changing environment." (Teece et al., 1997; Frasquet et al., 2013), have it that the immense challenges of international market obliges a firm to be flexible and quick enough to make use of opportunities. It means that the firm requires developing their capabilities for addressing diverse cultural and fast-moving environments.

Winter (2003) explained that the capability process consisted of operational (zero-level), dynamic (first-order), learning (second-order) capabilities, which are related to each other. And some research has showen that the path-dependent factors of dynamic capabilities: the past decisions, learning and knowledge management (Easterby-Smith \& Prieto, 2008; Winter, 2003).

In these processes, the significance of learning and accumulating information has been pointed out in some studies (Frasquet et al., 2013; Luo, 2002). This research pointed out that through learning from international partners, companies can gain advantage over local competitors and reconfigure capabilities, then constantly upgrade. It could be supposed that international companies could gain advantage and new knowledge from other international competitors who have been entering this new market earlier than them. Besides, Dawson (2007) proposed an imperative perspective to appreciate the knowledge transfer in international retailing that divided the type of knowledge to tacit and explicit knowledge. For being success in international expansion, it requires company to respond to both of the two types of knowledge transfers.

As a framework and method of studying on dynamic capability, Frasquet et al. (2013) showed characteristics and differences between the generic level and specific level in the internationalization process. Through an empirical study of five mid-sized apparel retailers of the UK, the indications showed that generic dynamic capabilities are 
focused on knowledge acquisition and learning and adaptation capability, while they entered second stage retailers are going to shift to brand building, channel management, customer relationship management.

Several research has carried out investigations that discovered that competitive advantages and adaptabilities of companies in a globalized and fast-moving environment are gained from the growth of vibrant capabilities (Cao \& Lanlan, 2011; Pitelis \& Teece, 2010). Despite these revelations, retail internationalization still calls for more empirical studies in diversified industries to better understand the development process and to help validate the approach and framework of dynamic capability.

Based on previous research of retail internationalization and the framework dynamic capability provided by Frasquet et al. (2013), this research aims to present the process of retail internationalization of a Japanese fashion company - Nice Claup that has entered the Chinese market since 2008 and has owed over 70 specialty stores in the mainland Chinese market and Hong Kong, Taiwan. It then discusses the possibility and the role of learning knowledge from a competitor while entering a new market with different culture and politics.

\subsection{Retailing in the Chinese Apparel Market}

Since 1990s, China has been positioned at the top of apparel production in the world with a lack of design ability, however, the country has had a comparative advantage in terms of low labor costs (Li et al., 2004)). After the accession to the WTO, most Chinese companies has to face the intense competition, as more and more international companies entering the Chinese market.

In the course of such changes, China's apparel industry has begun to shift in building their own brands and specialty stores by developing operations of producing and retailing ( $\mathrm{Li}$ et al., 2010; Miao, 2015). It is reflected in the birth of many retail brands and varied store formats in the current Chinese market. Many changes can be observed i.e. shopping malls in multiple price ranges, upscale shopping centres for high income and high levels of taste of apparel consumption, and flagship stores which are wholly-owned by manufacturers in China (Li et al., 2004). Especially, building their retail stores and designing and producing by applying vertical integration has been seen as an efficient approach for gaining competitive advantage. Therefore, they could control the whole supply chain by themselves and expand their product brand or store brand to an integrated mega brand (Miao, 2013; Li et al., 2004).

As the development of retailing, Chinese consumers are not only expecting high quality products, services, and broader merchandise assortments, but also good shopping condition, modern retail facilities and the performance on consumer protection (Trappey \& Lai, 1996). Many consumers prefer shopping in international shopping centers and specialty stores while their needs could not be satisfied by local retailers (Miao, 2015).

However, with the fierce competition, it is becoming more complicated for international companies to enter the Chinese market. It can be observed that the international expansion is affected by cultural and behavioral understanding, shopping conditions, purchase process, which are more important than the product itself (Trappey \& Lai, 1996).

In entering China, most international apparel retailers choose to rent a store space in department and shopping mall that could minimize the risk of their investment with lacking of network and information of local market. However, it can be observed that some mega brands are implementing a holistic marketing that involved product design, producing, retailing by developing a vertical agile supply chain, such as ZARA, H\&M, UNIQLO (Christopher \& Robert, 2004; Morash \& Steven, 2001; Minam et al., 2012).

Consequently, based on the research of retail internationalization and the development of retailing in China, this paper focuses on the distinct developing stages in the international expansion of a Japanese fashion retailer while entering the Chinese market. In the process, the changes on capabilities of each stage and the effect of a strategic branding which is called house branding. House branding is considered as a new format of specialty store, which aims to present an integrated brand concept with combining with distinct unique Japanese fashion brands within a special region as a big house. In other words, it intends to keep each brand's identity while cooperating with each other for gaining competitive advantage as a retail brand and catering to specific fashion lovers. Especially Nice Claup supposed to use multiple retail formats to target different customers as showed in figure 3 . Through the retail operations, we can see the interaction between retailing and edifice of customer relationship in the process of international expansion.

\section{Method}

In order to present the three distinct stages of international expansion and the development of dynamic capability, this study investigated the histories of international expansion of a Japanese fashion company-Nice Claup (Table 1) which has entered the Chinese market since 2000's. 
This paper adopted a qualitative narrative case study. The data and information of the Japanese apparel company were based on secondary and primary data gathered through in-depth interviews between 2015 and 2016 in Shanghai with department chiefs and executives who are charge of China branch office in Shanghai.

The interview survey was premeditated to indicate the history of entering the Shanghai's market since 2008 that included the obstructions of developing the Chinese market, learning knowledge from I.T. group (Table 2) - a fashion apparel company of Hong Kong, channel management, product adaptation, strategic retailing-house branding. Notably, the barriers to entering the Chinese market and the changes of each developing stage illustrated the rationale that forced international companies to be dynamic and flexible for the fast-moving environment in China.

Table 1. Company profiles

\begin{tabular}{llllll}
\hline Company & $\begin{array}{l}\text { Year } \\
\text { established }\end{array}$ & $\begin{array}{l}\text { Year } \\
\text { Entering China }\end{array}$ & $\begin{array}{l}\text { Turnover } \\
2015(\$ \text { millions })\end{array}$ & $\begin{array}{l}\text { No. of stores in Mainland } \\
\text { China }(2015)\end{array}$ & $\begin{array}{l}\text { Main current formats of } \\
\text { retailing }(2014)\end{array}$ \\
\hline Nice Claup & 1982 & 2008 & 82.24 & 72 & $\begin{array}{l}\text { 14(House Brand Store) } \\
\text { 12(Wholly Owned) } \\
\text { 46(Franchised) } \\
1 \text { (web) }\end{array}$ \\
\hline
\end{tabular}

Source: Nice Claup“Report 2016”.

Table 2. Company profiles

\begin{tabular}{llllll}
\hline Company & $\begin{array}{l}\text { Year } \\
\text { established }\end{array}$ & $\begin{array}{l}\text { Year } \\
\text { Entering China }\end{array}$ & $\begin{array}{l}\text { Turnover } \\
2015(\$ \text { millions })\end{array}$ & $\begin{array}{l}\text { No. of stores in Mainland } \\
\text { China }(2015)\end{array}$ & $\begin{array}{l}\text { Main current formats of } \\
\text { retailing }\end{array}$ \\
\hline I.T. group & 1988 & 2000 & 925.12 & 449 & $\begin{array}{l}364 \text { (Self-managed) } \\
85 \text { (Franchised) }\end{array}$ \\
\hline
\end{tabular}

Source: I.T "Annual Report 2016”.

\section{Findings: the Dynamic Development Process in the Chinese Market}

Nice Claup was founded in the early 1980s in Japan. It offers fast fashionable clothing for young women at middle and lower price. From 2008, it began to expand in the Chinese market, and established its first retail store in Shanghai. Based on interview survey, Nice Claup learned the idea of house branding from I.T Group who is leading young people's fashion trend in the mainland Chinese market, and then built its first house brand store in Shanghai's shopping mall by cooperating with other two Japanese apparel brands in 2012. So that Nice Claup strengthened its brand competitiveness and succeeded in promotion sales by bundling several items which could be coordinated together among these three brands.

Below is the development of Nice Claup in China. In the next paragraphs, the barriers of entering the Chinese market and how the company learned from local market and competitors can be observed.

\subsection{The Barriers of Developing the Chinese Market}

After the accession to the WTO, both of the local companies and international companies had to face intense competition in China, which led to a wide variety of retail brands and retailing formats in the current Chinese apparel market. Nonetheless, China's commercial retail sales are still padding behind many developed countries in terms of the level of retail operations and market normalization, and the emerging of multiple formats (Miao, 2013; Li et al., 2004). The giant commercial enterprises, such as department stores or shopping mall are still the main facilities for purchasing. It means that being able to enter these shopping facilities is the critical key for foreign companies to get success at the early expansion stage in China.

"We had to start our business through working with the local franchise partners and entering the large shopping centers of main cities. One of the reasons is that our own brand has not been recognized in China yet. We had to build brand awareness with the aid of the influential retailers first. Another one is that it is tough for us to get to know about the real information i.e. an excellent location for building a retail store, rental fee, local policy, shopping environment and local needs of the opaque market and the complexity of China. So that the current situation forced us to choose to exploit the Chinese market with franchise partners and enter into departments, 
despite the high risk of delivering management to local managers who have no idea about our brand" (Nice Claup's chief of the marketing department, Shanghai).

We can see that the non-transparent information is a kind of barriers to stunt foreign companies setting up business by themselves. Besides, there is a "tacit rule" of entering big shopping facilities, such as department stores and shopping malls.

"In order to get into the department stores in most of the main cities, we have to pay very high entrance fees in addition to the shop rent. In general, the location of our shops within the department stores are decided by the manager of the floor, who is given the full right by the department store for managing every shop in his floor. Most of the time we got a bad location which was behind an elevator or in a corner. It impacted our sales a lot" (Nice Claup's chief of marketing department, Shanghai).

Building retail store in a new market is a high perilous and thorny task for most international retailers. It requires a capability to understand the local needs and the non-transparent information, and also adapt all factors of brand to local market without misunderstanding of brand concept. While international retailers are insisting on their brands' concept, they have to learn a large amount of information and knowledge from local market.

\subsection{Branding with Standardization}

For most international apparel retailers, brand building is a key to open up market abroad. It requires retailers to have a competence in managing its brand dynamically and adapt the brand to new market with an inventive strategy. Frasquet et al. (2013) mentioned the dynamic capabilities of internationalization are to manage the adaptation of the brand to a market without losing brand integrity and present a brand with integrating product, channel, and systems tailored to the local market. In other words, branding should be centered on keeping its distinctiveness in all markets and adapting some factors of brand to the local market. The first stage for Nice Claup was to bring its brand identity unchanged from the Japanese market to the Chinese market.

Nice Claup insisted on its brand identity as a Japanese fashion with middle to low price, and targets the same segment, young ladies as well as in Japan market. In order to keep the concept of brand, all products was designed and produced by head office in Japan at that time. However, from 2012, Shanghai's branch office did a research on Chinese market and began to do some special design for local market. In 2015, 30\% of products have been designed by Shanghai's branch office.

In setting up retail stores, Nice Claup asked all of their retail store managers and their franchise store owners to adhere to their guidelines that were made by the head office in Japan. By reading the guidelines, they could get an understanding of the brand concept and implement the same retail operation.

"When I was going to be charge of a retail store in Jiuguang Department Store, I was told to attend a seminar for learning procedures that is about this brand's history and concept and retail management. For retail management, some parts could be decided by every local manager, such as the window displays, the interior decoration, sales approach, and employment. However, the main retail management, including assortment, retail price, outlet, inventory management, is following the guidelines" (The manager of Nice Claup, Jiuguang Department Store, Shanghai).

For most international apparel companies who are unaware in new market or lack of the competitiveness of outstanding products, their brands could be perceived by the design and outlets of their retail stores firstly. Therefore, the management of retail store is all important and has to be managed in an integrated way by standardization in the first step of internationalization, and the head office limits the manager's administration. Therefore, through this stage, it can be observed that the capability of managing an international brand is central to successfully transfer the brand concept from home market to the new local market. Even though, as a first step, standardization is a powerful way for raising brand awareness, a company still also has to be innovative in order to adapt to the Chinese market and gain competitive advantage.

\subsection{Product Design Adaptations}

In 2010, Nice Claup established its design team for the Chinese market in Shanghai. We can see that the percentage of each item designed by the local Chinese market design team has been steadily rising. It was revealed in the interview of the CEO of the branch office in Shanghai.

"We were shocked by the big difference of fashion preferences between Japan and China. It was so impressive. We believed that Japanese fashion styles would be preferred by Chinese consumers because we thought that so many young people were following Japanese fashion styles and most of them were enthusiastic to purchase items designed in Japan. But we were wrong. After starting the business in China, we realized that most 
consumers appreciate Japanese style coordination and some patterns, but not the colors and the feeling of size. We always heard from some of our staff that most people feel our size is tinier than their expectations. So now we know that we probably need to make some changes to our products." (Nice Claup's CEO of the branch office, Shanghai).

The design team renewed most items' magnitudes by following Chinese physique and the original color that is designed in Japan for meeting the local needs. It requires the capability of a company to find out the special local market needs and the distinction of dressing culture between the home market and the local market. It also asks the company to strike a balance between standardization and adaptation of design and production in order to ensure that the original brand uniqueness is not damaged by product design variation.

\subsection{Channel Management: Increasing Wholly-Owned Stores}

International apparel firms can select several channels to access the local markets. These include company-owned stores, franchising, in-shop stores, and Internet formats. International apparel retailers often use the amalgamation of the franchise and the direct-sale stores. We also can see that their strategic retail of different developing stages is distinct, while they are entering a new market. Therefore making a decision of channel management requires dynamic capabilities that keep a balance between direct and indirect channels in the changeable environment.

At the first stage, working with franchisees benefited Nice Claup, which is not only gaining local market presence by providing good locations and shopping environment, but also getting a lot of important knowledge and experience of the local market by working with the supply chain members in China.

Entering the second stage, Nice Claup intended to increase its brand awareness by adapting local market, and then started to build their stores in the Chinese market in 2010. However, even though Nice Claup realized that the complex conditions of entering the big shopping facilities is causing some loss to them, Nice Claup still continued to set up shops in department stores and shopping malls in the main cities of China. There are two reasons:

"Department store and shopping mall are the main shopping places for most local consumers. By entering the big department stores, we are able to gain a stable benefit by enhancing our awareness in China. Furthermore, running stores by ourselves is more competent and we can more rapidly adapt to the local market to solve the retailing problems more directly than our franchise stores are able to do. For instance, we can fine-tune the quantity of each item and find out the most popular items for additional production through the feedback from our owned stores" (Nice Claup's chief of marketing department, Shanghai).

Nice Claup intended to establish a competent vertical distribution system of production and retailing by enhancing their retail operations and shifting franchise stores to wholly-owned stores. From 2012 to 2016 , Nice Claup had increased the number of wholly-owned stores from 21 to 35 (including house brand stores and the normal type of flagship store). Meanwhile, Nice Claup decreased franchise stores from 62 to 45 (Figure 1). However, adverse conditions such as a high entrance fee and poor location of individual shops within department stores, and strong competition from European and American brands, forced Nice Claup develop differently at that time. 


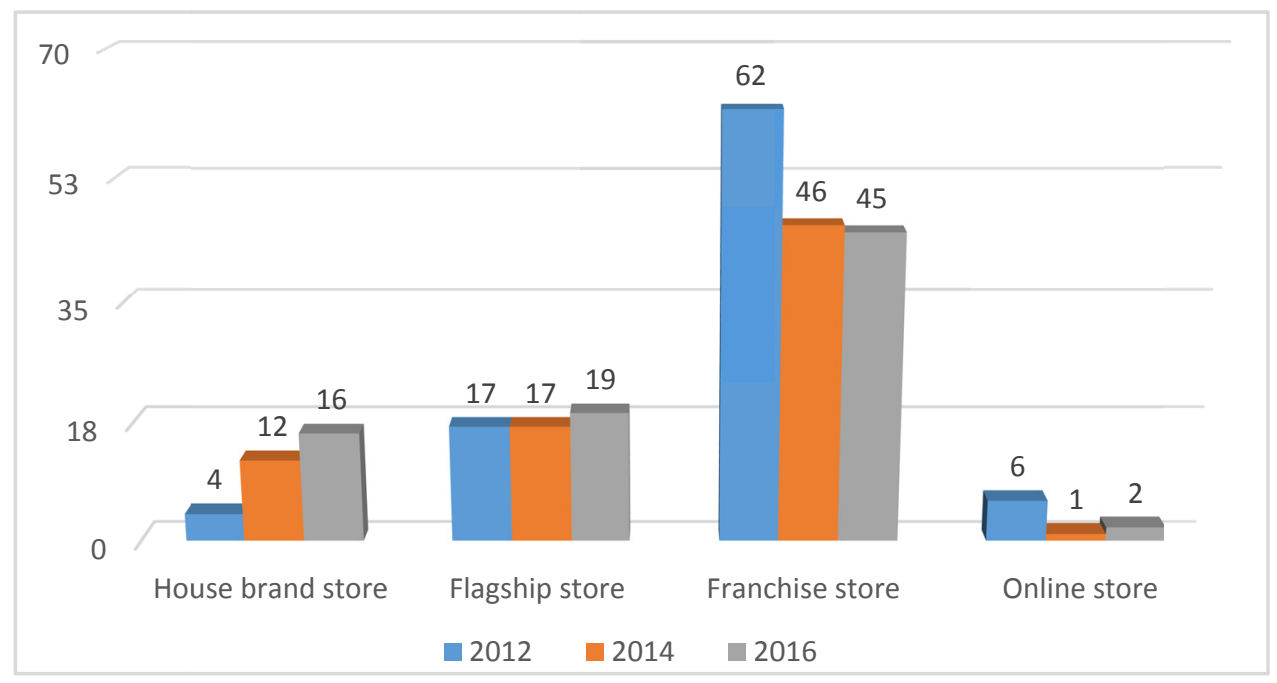

Figure 1. Numbers of stores

Source: Nice Claup“Report 2016”.

\subsection{Knowledge Acquisition and Learning}

In expanding a new market, there is much to learn from the local market, particularly when physical or psychic distance to the home market is large (Frasquet et al., 2013). Nice Claup was conscious of the lack of their local knowledge of the Chinese market, and therefore started to pay attention to local companies and successful multinationals. From 2011, Nice Claup noticed a new retail format invented by a Hong Kong company, called I.T Group.

"We found that the new format of I.T Group is playing a key role in gaining information from local markets, including retailing and fashion preference, through serving customers in a multi-brand shop. Meanwhile, I.T is succeeding in combining popular brands and unknown brands together for developing a new market" (Nice Claup's CEO of the branch office in Shanghai).

I.T Group, founded during the late 1980s in Hong Kong, proffers high-end clothing for men and women. Its rapid growth is supported by distinctive retailing strategy and cooperation with varied apparel brands and designers.

In 1988, I.T Group established a small 200 square-foot shop featuring brands in Hong Kong, and positioned itself as a fresh and fun fashion house. I.T defined itself as a place for young consumers to follow the forefront of fashion by selecting from a combination of multiple brands, all within that one same store. As I.T was entering the Chinese local market during the 1990s, I.T issued their unique retail store that was called, "house brand." House brand store intended to establish a network with new and unknown brands for getting an opportunity to test new market. Therefore, the solitary brand which is collected by I.T, even the one with a little-known, could have an opportunity to springboard into free-standing stores in the Chinese market without connection at all. Now I.T owned a number of house brand stores in Hong Kong, China, Taiwan, Canada, France, Japan, Philippines, Indonesia, and UK (I.T “Our Group”, HP: http://www.ithk.com/eng/html/about/index.html).

\subsection{A Special Retail Format: House Brand Stores}

After learning the concept of "house brand store" from I.T Group, Nice Claup started setting up their first house brand store using its own name "Nice Claup" in the Longemont shopping mall in Shanghai in 2012. This store sells three Japanese brands, Nice Claup, deux Nice Claup, and Majestic Legon, which all belong to three independent companies. Majestic Legon is a Japanese apparel brand which has established 14 retail stores in the Chinese market since 2008. However, it had been struggling with the high entrance fee and low awareness, like Nice Claup.

"We got an idea from I.T Group. We realized that we require unearthing other Japanese brands which are targeting the same segment in China. If we could work together in some way, we could establish a unique store together and share the high entrance fee. We can also reinforce the awareness of Japanese fashion style by branding the exceptional store. Then we found Majestic Legon, which was aiming to raise brand awareness, as 
we also were doing. However, they are targeting white-collar ladies by providing mature fashion styles. We thought we can compromise with each other." (Nice Claup's chief of marketing department, Shanghai).

At that time, although the house brand store was named for Nice Claup, each brand operated independently within the store and had a special space to flaunt their items, decorate their space with their own special decorations and sales focus, and display its brand name within its own space in order to keep each brand's identity. Nice Claup simply operated like the other brands within the store, but functioned as the administrator for the physical building, including merchandising, inventory, and stock management, as well as customer service, and cash handling.

After the first house brand store called "Nice Claup", Nice Claup got more experience and knowledge from running this special store. From 2012 to 2016, with the development of networks with other Japanese retailers, Nice Claup built 16 house brand stores in Shanghai, Shenzhen, Suzhou, Hangzhou, and other main conurbation in China, and renamed them "Miera Store". Miera Store is in conjunction with Majestic Legon, and another two popular Japanese fashion brands, "Remind me and forever" and "Cochinillo" (by Nice Claup).

"For Miera Store, on average, we rent a storefront of more than 800 square meters in department stores or shopping malls, and divide it to four areas, one for each brand. With the early stage, we didn't incorporate decorations and identification of our first house brand store "Nice Claup" because our original intention was to share the high entrance fee and strengthen the impression of Japanese fashion style. But after a period of time, we understood that we should complement each brand's items and strengthen the brand identity of Miera Stores, instead of each single brand. Since then we have started to build "Miera Store" as a retail brand with an integrated store design." (Nice Claup's CEO of the Shanghai branch office).

Store design is seen as an important approach for reflecting brand identify and communicating with consumers (Frasquet et al., 2013). Miera store is divided into four separate areas for the four brands in order to keep each brand's identity separate and unique. But the four areas are linked to each other by incorporating store design, using devices such as interconnected wallpaper, the same styling of rugs, murals, posters, furniture, and space layout. Especially in order to embed into the local market, Miera Store uses bright colors, such as red and yellow, to decorate the store space, which are the favorite colors of Chinese consumers?

Another important factor of Miera Store is providing training and mentoring for staff who are promoting the items of the four brands. Nice Claup asks every staff member working in Miera Stores to emphasize the item's price advantage by comparing items with US and European brands when talking to customers. The employees are also required to help customers coordinate various items from the four brands in order to promote having more matching outfits.

"We are always paying attention in order to train shopping advisers of Miera Store. All staffs working in Miera Store are required to comprehend or understand the Japanese fashion style, every brand's concept, the traits of the four brands, and how to help consumers to coordinate with different items within the four brands. We prefer to sell a suit of clothes to one single item. That's one of the competitive advantages of MieraStore." (Nice Claup's CEO of the Shanghai branch office)."

Since 2012, Nice Claup's brand awareness has improved constantly, and most young consumers can become aware of Japanese fashion styles as they tried picking and matching their clothes with the items in Miera Store. Sales volumes in 2016 for all 16 Miera Stores keep rising. It increased to 6,906 thousand dollars in 2016. All 16 stores produced more sales volume than all 45 franchise stores for the same period (Figure 2).

Compared to other store formats, the sales and sales volume of the Miera Store (Longemont shopping mall), both of the number of customers entering shops and purchasing are higher than other types of stores. Only the purchase rate is a little below the flagship store, but much higher than the franchise store in 2015 (Table 3). 


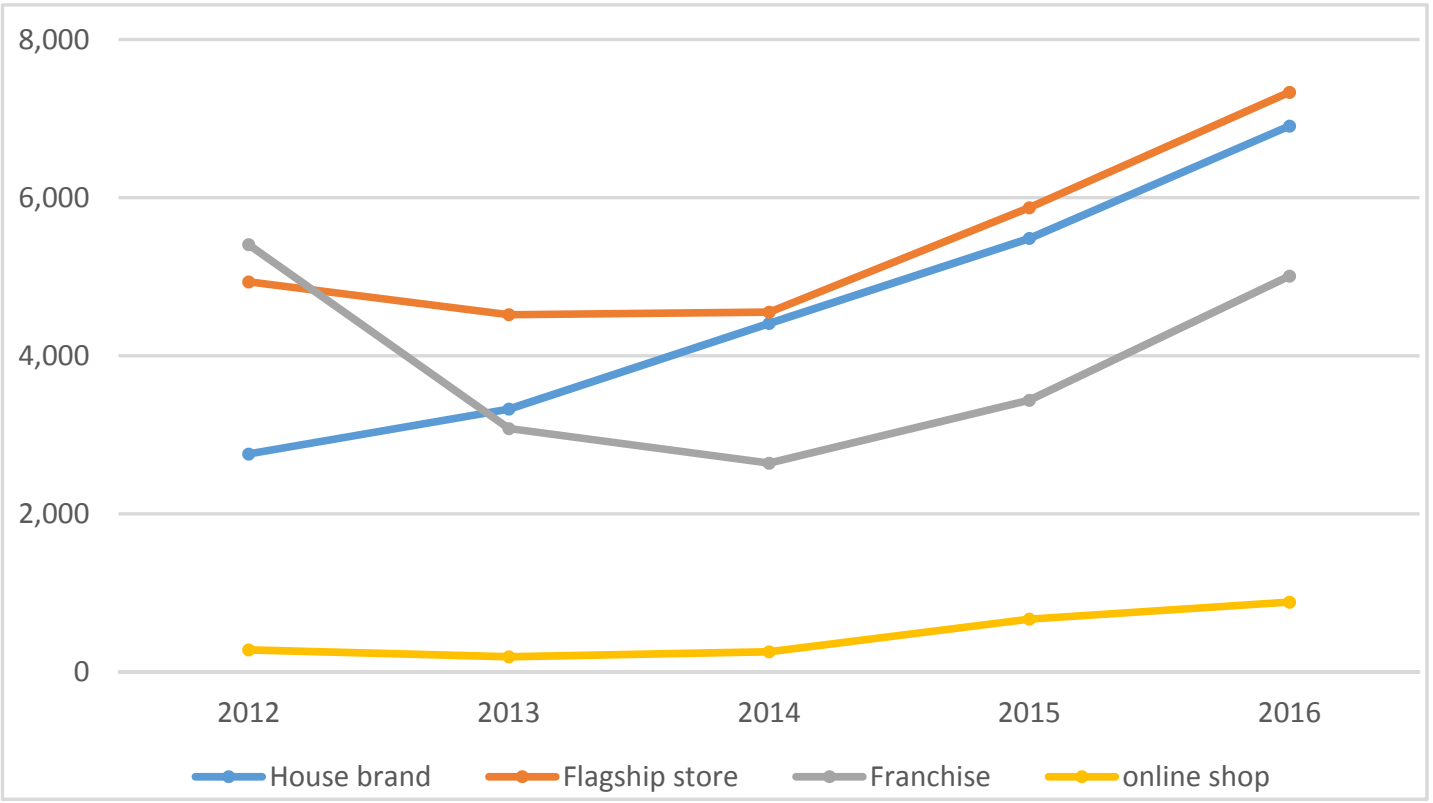

Figure 2. Sales footage (thousand dollars)

Source: Nice Claup“Report 2012, 2013, 2014, 2015, 2016”, Shanghai branch office.

Table 3. Comparison between house brand, flagship store and regular retail store

\begin{tabular}{llllll}
\hline $\begin{array}{l}\text { In } 2015 \text { per week } \\
\text { (average) }\end{array}$ & Sales & $\begin{array}{l}\text { Sales volume } \\
\text { (pieces) }\end{array}$ & $\begin{array}{l}\text { Number of customers } \\
\text { (entering the shop) }\end{array}$ & $\begin{array}{l}\text { Number of customers } \\
\text { (purchasing) }\end{array}$ & $\begin{array}{l}\text { Purchase } \\
\text { rate (\%) }\end{array}$ \\
\hline $\begin{array}{l}\text { Miera store* } \\
\text { (Longemont shopping mall) }\end{array}$ & $\begin{array}{l}85,713 \quad \text { yuan } \\
(12,445 \text { dollars) }\end{array}$ & 300 & 410 & 107 & 26.6 \\
$\begin{array}{l}\text { Flagship store } \\
\begin{array}{l}\text { (Jiuguang Department } \\
\text { in Shanghai) }\end{array}\end{array}$ & $\begin{array}{l}80,198 \quad \text { yuan } \\
(11,644 \text { dollars) }\end{array}$ & 249 & 285 & 90 & 33.4 \\
$\begin{array}{l}\text { Franchise store } \\
\text { (Parkson in Xi'an })\end{array}$ & $\begin{array}{l}52,650 \text { yuan }(7,644 \\
\text { dollars) }\end{array}$ & 106 & 450 & 45 & 10 \\
\hline
\end{tabular}

Note. *only calculate one brand "Nice Claup".

Source: Nice Claup "Report 2015" and interview with Nice Claup's CEO of Shanghai branch office.

\subsection{Cultivating the Customer Relationships with Diverse Retail Formats}

Cultivating the customer relationship is becoming the key-word for gaining client loyalty. Within the fashion industry, building retail stores with multiple formats has been practiced to attract more consumers and sustain competitive advantages (Guy, 1998; Miotto \& Parente, 2015). More and more retailers have started to provide more retail formats to satisfy different targets and demands (Fisher, 1997).

A management system of the customer relationship of Nice Claup is shown in Figure 3. While increasing the number of house brand stores, Nice Claup analyzed customers by their purchase behavior and preference and tried to cultivate customer relationship by different types of retail stores.

In the analysis, customers are divided into three types based on their purchasing behavior of four kinds of merchandise. These products include in-season items (original price), out-of-season items (10-20\% discount), last season's items (30-40\% discount) and last year's items (50-70\% discount). These four kinds of products make different levels of profits for the firm. 


\begin{tabular}{|c|c|c|c|c|c|}
\hline & & \multicolumn{3}{|c|}{ Customers } & \\
\hline & & C1 & C2 & డ & \\
\hline \multirow{6}{*}{ Products } & P 1 & o & & & $\begin{array}{l}\text { High Profitable } \\
\text { Product (in-season } \\
\text { item) }\end{array}$ \\
\hline & P 2 & & 0 & & $\begin{array}{l}\text { Profitable Product } \\
\text { (being out-of-season } \\
\text { item) }\end{array}$ \\
\hline & P 3 & & $\circ$ & $\circ$ & $\begin{array}{l}\text { Unprofitable Product } \\
\text { (last season item) }\end{array}$ \\
\hline & P4 & & & 0 & $\begin{array}{l}\text { High Unprofitable } \\
\text { Product (last year } \\
\text { item) }\end{array}$ \\
\hline & & $\begin{array}{l}\text { High-profit } \\
\text { Customer }\end{array}$ & $\begin{array}{l}\text { Mixed-bag } \\
\text { Customer }\end{array}$ & \begin{tabular}{|l} 
Losing \\
Customer
\end{tabular} & \\
\hline & & $\begin{array}{l}\text { House Brand } \\
\text { Store }\end{array}$ & Flagship Store & $\begin{array}{l}\text { Franchise } \\
\text { Store/Outlets } \\
\text { /Online }\end{array}$ & \\
\hline
\end{tabular}

Figure 3. Customer relationships with diverse retail formats

Source: Based on Kotler \& Keller (2016), p. 84 and an interview with Nice Claup's CEO of Shanghai branch office.

Based upon this grouping below, three types of customers can be observed, $\mathrm{C} 1, \mathrm{C} 2$, and $\mathrm{C} 3$. C1 customers always purchase highly profitable products (in-season items) and thus make large profits for Nice Claup. C2 customers are called "mixed-bag" customers because they purchase both profitable and unprofitable items (both out-of-season and last season's items). C3 clientele always purchase highly unprofitable items (last year's items). To target $\mathrm{C} 1$ customers, Nice Claup offered high-quality services, such as coordination with multiple brands and various abolished items at their house brand stores. To target $\mathrm{C} 2$ customers, Nice Claup offered big-sized flagship stores that offered lots of out-of-season and last season's products. C3 customers were targeted by sales promotions for franchise stores, outlets, and online stores.

"We tried to create $\mathrm{C} 1$ customers, who purchase in-season items and thereby making high profits for us, by providing high quality services, while encourage customer 3 to switch to franchise stores and outlets, an online store by doing sales promotion. For customer 2 who are purchasing both of profitable product and unprofitable product, we targeted them by big-sized flagship stores. For targeting these different kinds of customers, we built different types retail stores at various locations. For example, we built our flagship stores in shopping facilities which are nearby subway station for benefiting $\mathrm{C} 2$ customer. Because we know that these kinds of customers prefer items with a discount and do shopping by using public transport. For building house brand stores, we look for a place within a shopping facility or an area which has a good sense of fashion and gathers young people who are willing to try new fashion styles. In short, we intend to attract different customers and satisfy them by our unique retail stores."(Nice Claup's CEO of Shanghai branch office).

\section{Discussion and Conclusion}

Based on the review of retail internationalization, dynamic capabilities and the background of retailing in the Chinese market, this paper is determined to demonstrate a process of retail internationalization of a Japanese fashion retailer, and divide the process into three stages by distinct characteristics and strategic developments. Through this process, we can see that how the company gained new capabilities while developing in the three stages and the factors impacting international expansion in China.

In this paper, the empirical study of the Japanese apparel retailer-Nice Claup is based on the framework of dynamic capability that is provided by Frasquet et al. (2013). Through the case study, this paper improved the framework to be three developing stages with different tasks, which are transferring brand concept with standardization, increasing brand awareness with adaptation and customer relationship management (figure 4). It also showed that Nice Claup gained new capabilities because of the barriers of expanding the Chinese market and the limitations of each stage. 


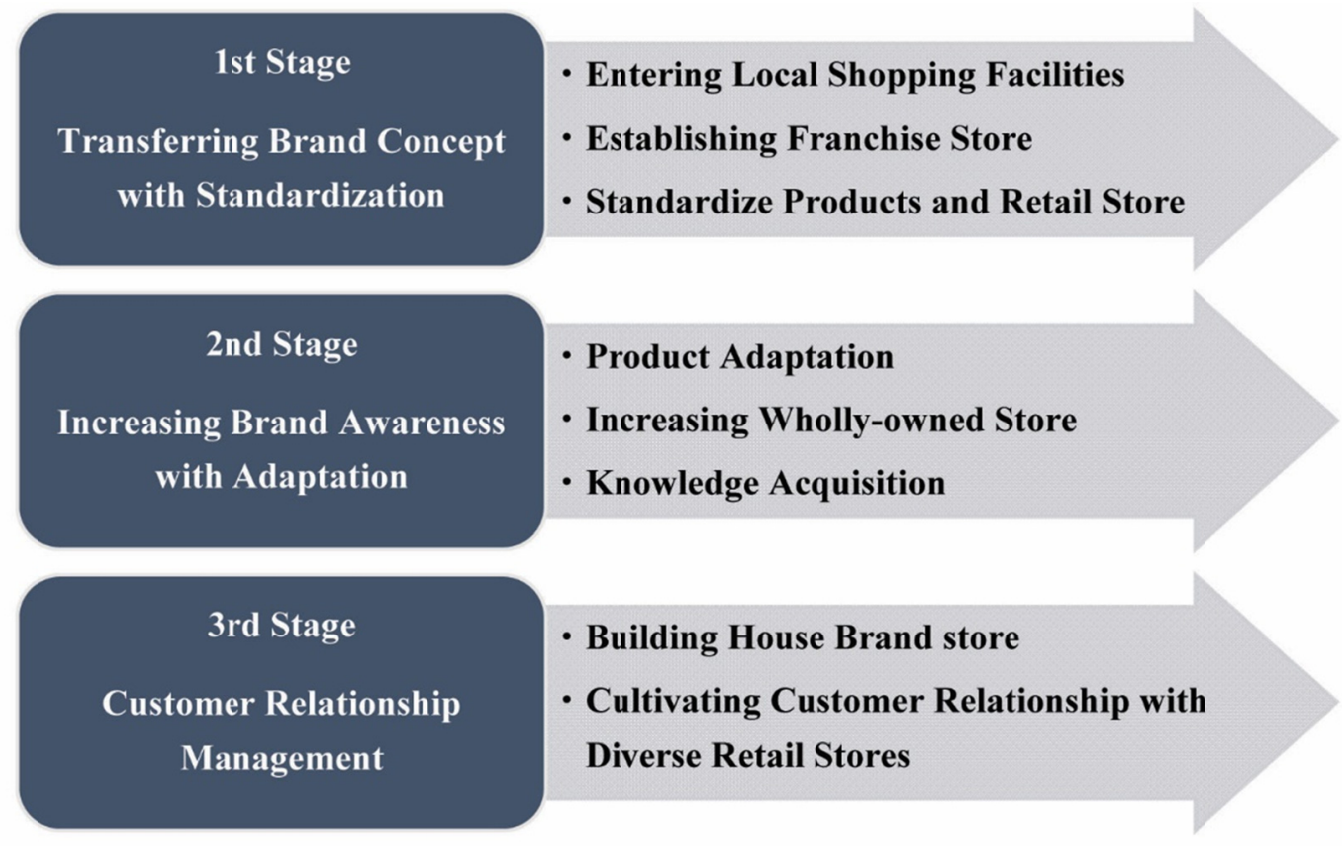

Figure 4. A framework of strategic shift of retail internationalization

Based on the interview survey, the findings are aimed to elucidate the distinct characteristics and strategic shift of each stage. Since entered the Chinese market, Nice Claup has shifted their focus from standardization to adaptation, and to cultivate customer relationship with multiple sale channels and retail formats within only 9 years.

\section{(1) First Stage:}

The first stage of standardization scrutinized that working with local retailers and entering the main shopping facilities were decisive in starting their retail business in the Chinese market, as well as transferred its brand concept without losing the brand uniqueness or identity. Nice Claup has had a high capability and operation of retailing as a Japanese fashion retailer since being established in 1982. However, while Nice Claup chose to develop the Chinese market that is unique with some non-transparent information and tacit rules, it was required that one should have a new learning capability about the local market and finding out an effective sale channel for opening up the Chinese market. At this stage, the rationale is not only for gaining sale channels, but also getting a capability of retailing with standardization and transferring the brand concept from home market to local market without losing its brand identity. For opening up the market, we can see that the local supply chain members are the important mediators between customer and firm. They are acting the role of communicating with customer and helping firm to know who its customer is.

However, in increasing brand awareness, adapting both product and retail to the local market is required in the next stage. We can see the strategic shift towards to increasing wholly-owned stores to replace of franchise stores in the second stage.

\section{(2) Second Stage:}

When Nice Claup realized the big difference of fashion preference between Japan and China, it was shifted to adapt the Chinese market with setting up their own design team for local market and increase their wholly-owned stores for enhancing brand awareness. However, the strategic budge requires new competence of a company to find out the special local market needs and the peculiarity of dressing culture, and strength their retail operation for meeting local needs. Nice Claup gained these capabilities by working with local franchisees and being through barriers of entering shopping facilities from the first stage. Thus, we can say that this stage is preparing for gaining new capabilities of channel management and product adaptation, and also provided a chance of learning a concept of house brand store from one of the competitors, I.T Group.

\section{(3) Third Stage:}

Based on learning about the Chinese market which includes both tacit and explicit knowledge from competitors, 
Nice Claup gained knowledge to solve the high entrance fee problem by reconfiguring their capabilities into a new retail format - the "house brand store", which they named, "Miera." The house brand store is defined as a retail format which gathers dissimilar autonomous apparel brands into one large store. It resembles a house in that each brand within the house brand store have their own detach areas for keeping each brand's identity but are connected to each other by integrated store design, such as interconnected wallpaper, same styling of rugs, murals, posters, furniture, and space layout. In this study, Nice Claup has the administrative permission to operate this house brand store.

Through establishing house brand stores, Nice Claup is able to: (1) dwindle the risk of entering the Chinese market as a single retailer and thus evade paying the high entrance fee of entering shopping facilities by themselves by sharing the same building space with the three other brands participating in the house brand store; (2) get market share and enhance brand awareness by cooperating with the other brands; (3) create a concept of Japanese fashion style by complementing other Japanese brands within house brand store.

The house brand store also indicated an interface between developing assorted retail stores and cultivating customer relationships as shown in the figure 3. In this interaction, Nice Claup targets different customers by operating diverse retail stores. Nice Claup encourages mixed-bag customers to purchase at flagship stores with out-of-season items, and promotes losing-customers to purchase out-of-season items at franchise stores, outlets, and online stores. By serving diverse types of customers with multiple retail stores, Nice Claup increased its brand awareness and gained an organized relationship map with different types of customers.

From the conclusions of this empirical study, the process of retail internationalization and branding can be developed for the future study. This case study could be substantiation for improving the research on dynamic capability and the interaction between retail operation and customer relationship management. We can see that Nice Claup segmented the Chinese market by operating multiple retail stores, and each retail store plays a discrete role of cultivating customer relationship. This paper also specified a possibility of retail internationalization with cooperating between small and medium-sized firms. However, the factors impacting on dynamic capability and development of growth tactic require more manifold research and development.

\section{References}

Brun, A., \& Castelli, C. (2008). Supply chain strategy in the fashion industry: Developing a portfolio model depending on product, retail channel and brand. International Journal of Production Economics, 116(2), 169-181. https://doi.org/10.1016/j.ijpe.2008.09.011

Corstjens, M., \& Lal, R. (2012). Retail doesn't cross borders: here's why and what to do about it. Harvard Business Review, 90(4), 104-111.

Dawson, J. A. (2007). Scoping and contextualising retailer internationalization. Journal of Economic Geography, 7(4), 373-397. https://doi.org/10.1093/jeg/lbm009

Deloitte. (2009). International retailing-Folding growth in challenging times. Deloitte, London.

Easterby-Smith, M., \& Prieto, I. M. (2008). Dynamic capability and knowledge management: an integrative role $\begin{array}{llll}\text { for learning? British Journal of } & \text { Management, } 19, \quad \text { 235- }\end{array}$ https://doi.org/10.1111/j.1467-8551.2007.00543.x

Faultrier, B., de Boulay, J., Feenstra, F., \& Muzellec, L. (2014). defining a retailer's channel strategy applied to young consumers. International Journal of Retail \& Distribution Management, 42(11-12), 953-973. https://doi.org/10.1108/IJRDM-02-2014-0018

Fisher, M. L. (1997). What is the right supply chain for your product? Harvard Business Review, 3-4, 105-116.

Frasquet, M., Dawson, J., \& Molla, A. (2013). Post-entry internationalisation activity of retailers. Management Decision, 51(7), 1510-1527. https://doi.org/10.1108/MD-02-2013-0081

Goldman, A. (2001). The transfer of retail formats into developing economics: the case of China. J. Retail, 77(2), 221-242. https://doi.org/10.1016/S0022-4359(01)00044-6

Guy, C. M. (1998). Classification of retail stores and shopping centres: some methodological issues. Geo Journal, 45, 255-264. https://doi.org/10.1023/A:1006960414161

Kotler, P., \& Keller, K. L. (2016). A framework for marketing management (6th ed.). White plains, NY: Pearson.

Kremer, F., \& Viot, C. (2012). How store brands build retailer brand image. International Journal of Retail \& Distribution Management, 40(7), 528-543. https://doi.org/10.1108/09590551211239846

Lavin, M. (2009). Marshall Field's becomes Macy's: understanding retail brand. International Journal of Retail 
\& Distribution Management, 37(11), 993-1007. https://doi.org/10.1108/09590550910999398

Li, J., Wang, Y. \& Cassill, N. L. (2004). A comparative study on new retailing outlets in the shanghai apparel market. Journal of Fashion Marketing and Management, 8(2), 166-175. https://doi.org/10.1108/13612020410537861

Li, X. (2010). The adoption of the "SPA" model by china's largest men suits manufacturer- A case of Youngor Group. Journal of Marketing and Distribution, 42(4), 49-66. (In Japanese)

Miao, M. (2013). Diversified development of SPA: case study on Chinese apparel company ERDOS Group. Social System Study, 27, 51-88. (In Japanese)

Miao, M. (2015). The transformation from vertical integration to SPA model-case study on ANTA Sports Products Limited. Ritsumeikan Business Journal, 9, 19-45. (In Japanese)

Miotto, A. P., \& Parente, J. G. (2015). Retail evolution model in emerging markets:apparel store formats in Brazil. International Journal of Retail \& Distribution Management, 43(3), 242-260. https://doi.org/10.1108/IJRDM-03-2012-0025

Newman, A. J., \& Cullen, P. (2002). Retailing: environment and operations. Boston: Cengage Learning EMEA.

Olsen, N. V., \& Sallis, J. E. (2010). Processes and outcomes of distributor brand new product development. International Journal of Retail \& Distribution Management, 38(5), 379-395. https://doi.org/10.1108/09590551011037590

Picot-Coupey, K. et al. (2012). Retailers' expansion mode choice in foreign markets: Antecedents for expansion mode choice in the light of internationalization theories. Journal of Retailing and Consumer Services, 21, 976-991.

Pitelis, C. N., \& Teece, D. J. (2010). Cross-border market co-creation, dynamic capabilities and the entrepreneurial theory of the multinational enterprise. Industrial and Corporate Change, 9(4), 1247-1270. https://doi.org/10.1093/icc/dtq030

Teece, D. J., Pisano, G., \& Shuen, A. (1997). Dynamic capabilities and strategic management. Strategic $\begin{array}{lll}\text { Management } & \text { Journal, } & \text { 509-533. }\end{array}$ https://doi.org/10.1002/(SICI)1097-0266(199708)18:7<509::AID-SMJ882>3.0.CO;2-Z

Trappey, C. V., \& Lai, M. K. (1996). Retailing in Taiwan: modernization and the emergence of new formats. International Journal of Retail \& Distribution Management, 24(8), 31-37. https://doi.org/10.1108/09590559610150366

Wigley, S., \& Moore, C. (2007). The operationalization of international fashion retailer success. Journal of Fashion Marketing and Management, 11(2), 281-296. https://doi.org/10.1108/13612020710751437

Winter, S. (2003). Understanding dynamic capabilities. Strategic Management Journal, 24, 991-995. https://doi.org/10.1002/smj.318

\section{Copyrights}

Copyright for this article is retained by the author, with first publication rights granted to the journal.

This is an open-access article distributed under the terms and conditions of the Creative Commons Attribution license (http://creativecommons.org/licenses/by/4.0/). 